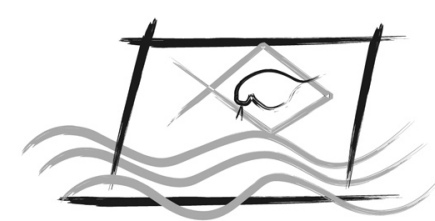

ECOTOX - BRASIL

\title{
Genotoxicity evaluation of tilapia (Oreochromis niloticus) exposed to waters from two sites of Itajaí-Açu River (SC, Brazil)
}

\author{
A. BÜCKER ${ }^{1 *} \&$ M. B. DA CONCEIÇÃOO \\ ${ }^{1}$ Laboratório de Biologia Molecular e Biotecnologia de Leveduras (LBMBL), Centro de Ciências Biológicas (CCB), Universidade Federal \\ de Santa Catarina (UFSC). Campus Universitário, Trindade, CEP 88040-970, Florianópolis, SC, Brazil. Tel: +55 48 3721 -6919. \\ ${ }^{2}$ Laboratório de Bioquímica e Biologia Molecular (LBBM), Centro de Ciências Tecnológicas da Terra e do Mar (CTTMar), Universidade \\ do Vale do Itajaí (UNIVALI). Rua Uruguai n 458, Centro, CEP 88302-202, Itajaí, SC, Brazil. Tel: +55 47 3341-7716.
}

(Received April 16, 2010; Accept Septemper 09, 2010)

\begin{abstract}
The relationship between the genes and the effects attributed to them has been object of many studies, especially those seeking to establish the response of genes to environmental prod. The aim of this work was to establish a standard system to monitor effluents by using juvenile Nile tilapia (Oreochromis niloticus) as a bioindicator of genotoxicity, utilizing micronuclei test and comet assay. For this, the fish were exposed during 24, 48, 72 and 240 hours (10 days), to water samples collected at two sites of the Itajaí-Açú River: Ilhota and Blumenau, in the Santa Catarina State, Brazil. For positive control the herbicide 2,4-D (75 $\mathrm{ppm}$ ) was utilized, and the negative control of each fish were the values obtained before the exposure to the river water, termed time zero $\left(\mathrm{T}_{0}\right)$. Water samples from both sites of the Itajaí-Açú River showed significant genotoxic effects in erythrocytes of the exposed fishes. The comet assay was a more sensitive test to detect genotoxic damage in shorter exposure times (24 and 48 hours) than the micronuclei test.
\end{abstract}

Key words: genotoxicity, comet assay, micronuclei test, Oreochromis niloticus, bioindicator

Avaliação da genotoxicidade em tilápias (Oreochromis niloticus) expostas às águas de dois locais do Rio Itajaí-Açu (SC, Brasil)

\section{Resumo}

A relação entre os genes e os efeitos a eles atribuídos tem sido objeto de muitos estudos, sobretudo aqueles que buscam estabelecer a resposta dos genes aos estímulos ambientais. Este estudo teve por objetivo padronizar um sistema de monitoramento de efluentes tendo juvenis de peixes exóticos da espécie tilápia (Oreochromis niloticus) como bioindicadores de genotoxicidade, utilizando as técnicas do teste do micronúcleo e ensaio cometa. Para isto, os peixes foram expostos no período de 24, 48, 72 e 240 horas (10 dias) às amostras de água coletadas em dois locais do Rio Itajaí-Açú: Ilhota e Blumenau, no Estado de Santa Catarina, Brasil. De controle positivo foi utilizado o herbicida 2,4-D (75ppm), e para o controle negativo foram atribuídos os valores obtidos de cada peixe antes da exposição às águas do rio, determinado como tempo zero $\left(\mathrm{T}_{0}\right)$. As amostras de água de ambos os pontos de coleta do Rio Itajaí-Açú mostraram efeitos genotóxicos significativos nos eritrócitos dos peixes expostos. O ensaio cometa mostrou ser mais sensível para detectar danos genotóxicos, nos menores tempos de exposição em relação ao teste do micronúcleo.

Palavras-chave: genotoxicidade, ensaio cometa, teste do micronúcleo, Oreochromis niloticus, bioindicador. 


\section{INTRODUCTION}

Pollution is spreading at unperceived speed, and there is a growing concern about water resources, in particular about conserving the environmental conditions necessary for survival for wild life aquatic organisms. For this, the knowledge of the quality of the natural water bodies, like lakes, streams, rivers, sees and others is essential, as are studies which evaluate the impact that pollution exerts on living beings, providing the necessary argument to enable adequate conservation, management and development programs (Barnhoorn \& Van Vuren, 2004).

The sources of pollutants to water reservoirs are diverse, the most significant of them being city sewage, industrial waste and agricultural pesticides and fertilizers, which drain into rivers and may leach into the groundwater. Within the pollutants are many unlisted genotoxicants or products which originate them, whose consequences go beyond the killing of local organisms, affecting in unpredictable manner the generations to come, not only of aquatic organisms, but of all who depend on that water as drinking source (Claxton et al., 1998; Jha, 2004; Moron et al., 2006).

The Itajaí-Açú river, with an extension of $200 \mathrm{Km}$, is the main river of Santa Catarina state, draining a region of $15,500 \mathrm{Km}^{2}$, it crosses some of the most important cities of the state, like Brusque, Blumenau and Itajaí, receiving direct wastes from over 60 major polluting industries, mostly textile, metal-mechanic, fishery, soya oil, paper and starch-producing undertakings, so as spill waste from about 900,000 people, among other urban residues, most of them without any pretreatment. The region is problematic, and the river, which often is colored in the dyeing tints of the textiles, is the source of the drinking water and for industrial use (Santos, 1996; Pereira-Filho et al., 2003).

In the present paper, the micronucleus test (MNT) and the single cell gel electrophoresis (SCGE), were used to study the genotoxic potencial of Itajaí-Açú water by using erythrocytes of tilapia (Oreochromis niloticus)-as bioindicator. The MNT is a very sensitive and useful method that can detect both clastogenic and aneugenic activity (Al-Sabti \& Matcalfe, 1995), and has been widely used as tool for the monitoring of water quality (Buschini et al., 2004; Maffei et al., 2009). Comet assay, first developed by Singh et al. (1988), is frequently used to evaluate the genotoxicity in environmental monitoring studies (Silva et al., 2000; Frenzilli et al., 2009). In literature, several in vitro and in vivo studies with the comet assay in fish are reported (Maffei et al., 2009; Hartmann et $a l ., 2004)$ and the usefulness of this test in fishes as a model for monitoring genotoxicity of aquatic habitats seems widely accepted (Russo et al., 2004; Frenzilli et al., 2009). The MNT is often applied in conjunction with the comet assay under alkaline conditions (Belpaeme et al., 1998; Buschini et al., 2004; Bücker et al., 2006). Alkaline ( $\mathrm{pH}>13$ ) version of the comet assay is capable of detecting DNA single-strand breaks, alkali-labile sites and DNA-DNA/DNAprotein cross-linking (Tice et al., 2000; Christofoletti et al., 2009).
The Nile tilapia $O$. niloticus is considered a good bioindicator for genotoxicants in water resources and for environmental monitoring (Andrade et al., 2004a; Masutti et al., 2006; Grisolia et al., 2009). The choice of these species is because it is easily obtained and already well adapted to climactic conditions of Brazil. The Nile tilapia $O$. niloticus also have a commercial value added and it is cultivated in many regions of Brazil and according to FAO (1998) the tilapia is the most cultivated cichlid in the world.

The aim of this study was to develop a system using juvenile Nile tilapia as an in vivo diagnostic tool for the screening of environmental genotoxic effects of water obtained from the Itajaí-Açú River, Brazil.

\section{MATERIAL AND METHODS}

\section{Samples}

For the bioassay, juvenile specimens of the exotic species Oreochromis niloticus (Perciformes, Cichlidae), commonly known as Nile tilapia, were supplied by the Empresa de Pesquisa Agropecuária e Extensão Rural de Santa Catarina S.A. (EPAGRI), Hatchery Station from Camboriú city. Prior to the genotoxic tests individuals were acclimated to laboratory conditions for a week in tanks of 500 liters of tap water with aeration. After that a total of the 20 individuals (averaging $14 \pm 5$ $\mathrm{g}$ in weight and $15 \pm 2 \mathrm{~cm}$ in length) 10 per each test, were used to test the waters of the Itajaí-Açú River at laboratory conditions. Fishes were exposed in 500 liter tanks filled with 200 liters of water from two locations. The sample point 1 (Ilhota) was located in Ilhota city (26 $\left.54^{\prime} 09.92^{\prime \prime} \mathrm{S}, 48^{\circ} 49^{\prime} 54.18^{\prime \prime} \mathrm{W}\right)$ and the sample point 2 (Blumenau) in Blumenau city $\left(26^{\circ} 55^{\prime} 12.81^{\prime \prime} \mathrm{S}\right.$, $49^{\circ} 03^{\prime} 31.90^{\prime \prime} \mathrm{W}$ ), both sample sites are in Santa Catarina State, Brazil (Fig.1). After exposition, blood was collected from the caudal vein of all fish at time zero $\left(\mathrm{T}_{0}\right)$ and after $24,48,72$ and 240 hours of exposure and utilized to both micronucleus and comet assay tests. For each test, one slide was mounted per fish for each time of exposure. The fishes were not fed during the experiment and the temperature was ranging from 20 to 23 ${ }^{\circ} \mathrm{C}$ under constant aeration.

The positive control group consisted of 12 individuals exposed to a sub-lethal concentration ( $75 \mathrm{ppm}$ ) of the herbicide 2,4-Dichlorophenoxyacetic acid (CAS No. 94-75-7, 98\% purity) in buckets of 30 liters of capacity (Ateeq et al., 2002). The 2,4-D (DMA 806 BR, Dow Agrosciences Ind. Ltda) was supplied by the Experimental Station of EPAGRI from Itajai city (Santa Catarina State, Brazil).

\section{Micronucleus test (MNT)}

The MNT first described by Schmidt (1975), was performed according to Grisolia and Cordeiro (2000) with minor modifications. Blood samples were obtained by caudal vein puncture using a heparinized syringe and smeared immediately onto clean glass slides; air dried overnight, and 


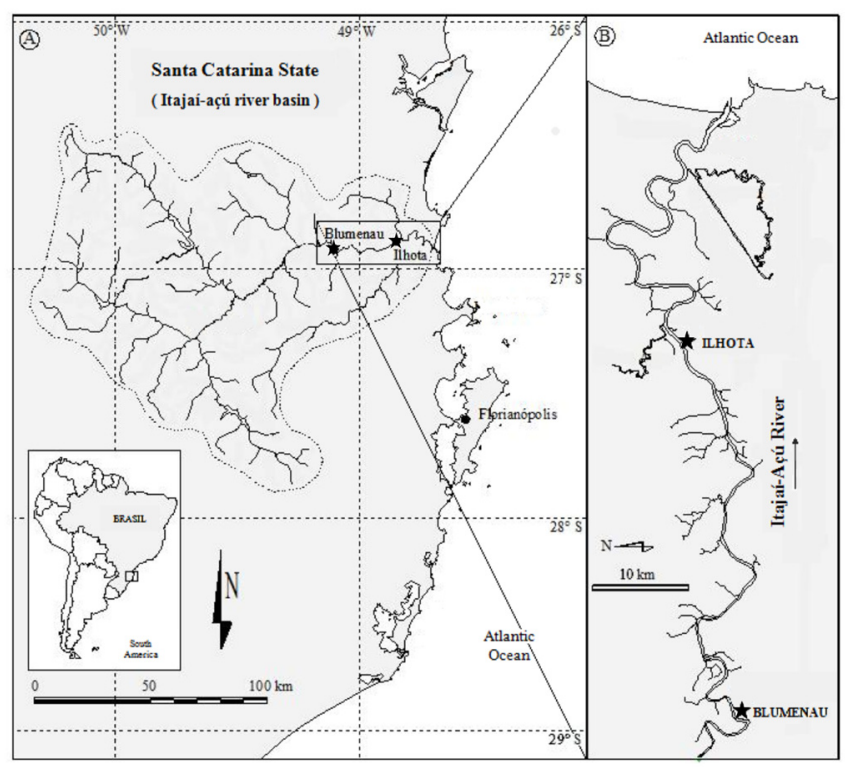

Figure 1. Map of the Brazilian state Santa Catarina (A), showing the Itajaí-Açú river basin (dashed line) and location of two sample sites (B) in Blumenau and Ilhota (closed stars).

then fixed in absolute methanol for $15 \mathrm{~min}$ and stained with $5 \%$ Giemsa solution for $15 \mathrm{~min}$. At least 1,000 erythrocytes for each $O$. niloticus specimens were examined using a light microscope. Micronucleus (MN) were identified and scored microscopically under $100 \mathrm{x}$ objective in an Olympus microscope. The main criteria for scoring the MN were the absence of connections with the main nucleus and a size smaller than $1 / 10$ of the nucleus.

\section{Alkaline Comet assay}

The alkaline comet assay was performed basically as described by Hartmann et al. (2004). Fish blood, samples were collected from the caudal vein with a syringe. A $10 \mu \mathrm{L}$ aliquot of fish blood was taken from each diluted sample and mixed with $75 \mu \mathrm{L}$ low-melting-point (LMP) agarose $(0.5 \%)$. The suspension was spread on slides previously coated with normal agarose, prepared in phosphate-buffered saline (PBS), which were then covered with a cover slip and conditioned in the refrigerator at $4^{\circ} \mathrm{C}$ for $20 \mathrm{~min}$, so that the agarose could solidify and the cover slip was carefully removed and a second layer of LMP agarose was added $(75 \mu \mathrm{L})$. After agarose solidification, the cover slip was removed and slides were immersed into lysis solution $\left(2.5 \mathrm{M} \mathrm{NaCl}_{2}, 100 \mathrm{mM} \mathrm{Na} 2\right.$ EDTA, $10 \mathrm{mM}$ Tris, $\mathrm{pH} 10,1 \%$ sodium sarcosinate with $1 \%$ Triton $\mathrm{X}-100$, and $10 \%$ DMSO added just before use) for at least 20 minutes, at $4^{\circ} \mathrm{C}$. Afterwards, slides were washed in ice-cold PBS in order to remove excess of salt and detergents, left in electrophoresis buffer $(0.3 \mathrm{mM} \mathrm{NaOH}, 1 \mathrm{mM}$ EDTA, $\mathrm{pH}>13)$ during $20 \mathrm{~min}$ for DNA unwinding, and electrophoresed in the same buffer for 20 minutes $\left(0.8 \mathrm{~V} \mathrm{~cm}^{-1}\right)$. Following electrophoresis, slides were neutralized in $400 \mathrm{mM}$ Tris- $\mathrm{HCl}(\mathrm{pH} 7.5)$, for $10 \mathrm{~min}$. And fixed in absolute ethanol (for $5 \mathrm{~min}$ ), let dry on air and stored in the dark until analysis. Observations were made on Olympus fluorescent microscope $(1,000 \mathrm{x})$. The slides were stained at moment of analyses with DAPI (4,6-Diamidino-2fenilindol) $\left(3 \mu \mathrm{g} \mathrm{mL}^{-1}\right)$. A total of 100 comets were scored for each individual.

The samples were compared with the negative control group exposed to the hatchery water and the positive control 2,4-D (75 ppm) only at the 24 hours of exposure, which was the time proved to have been sufficient enough to show extensive DNA damage. All slides were independently coded and scored by a single observer. DNA migration was determined visually by the categorization of comets into different classes of migration. The damage classes were: I - II - III - IV - V - VI, and to the statistical analysis was attributed number values (Ranks) from 0 until 5 to each one of these classes. The parameters measured to analyze the electrophoretic patterns follow criteria proposed by Tice et al. (2000). Therefore, after get the frequencies for each damage class, it was calculated the sum of the ranks to each slide sample (individual), and this result was utilized to the comparison of the exposure times. Statistical analysis was performed using the non-parametric Mann-Whitney $U$-test, with the level of significance set at $\mathrm{p}<0.05$.

\section{RESULTS AND DISCUSSION}

The evaluation of wastes and effluents by genotoxicity assays provides useful data for hazard identification and comparative risk assessment (Claxton et al., 1998). In our study we collected erythrocytes by caudal puncture of the $O$. niloticus without the need of sacrificing animals to conduct the study, and this was done after one week for acclimation $\left(\mathrm{T}_{0}\right)$, and 24 hours, 48 hours, 72 hours and 10 days of exposure. The fish demonstrated resistance to the stress of handling and the blood collection, corroborating data of Lemos et al. (2005) with other tilapia species, Tilapia rendalli, where the specimens could be returned to the environment after similar experimental procedures. That what was not the case when we used the electric fish Eingenmannia virescens (Bücker et al., 2006) or Apteronotus bonapartii (Carvalho et al., 2006; Bücker et al., 2012), where a significant amount of fish died, probably because of the blood collection stress.

The positive control, 2,4-D, caused a time-dependent increase of MN and extensive DNA damage at $24 \mathrm{~h}$ (Fig. 2 and 3 ), serving well as positive control for both assays, corroborating findings of Ateeq et al. (2002), were the herbicide 2,4-D was found to be genotoxic as well as cytotoxic in catfish Clarias batrachus, with a positive dose-response relationship.

\section{MNT}

Figure 2 shows the results for the MNT. Samples from Blumenau showed significant $\mathrm{MN}$ induction at 48, 72 and $240 \mathrm{~h}$ (10 days) of exposure. On the other hand, samples from Ilhota showed significant MN induction only at $72 \mathrm{~h}$ of exposure. The individuals exposed to the herbicide 2,4-D showed significant MN induction when compared with the negative control and also with individuals exposed to water samples from Ilhota and Blumenau. 


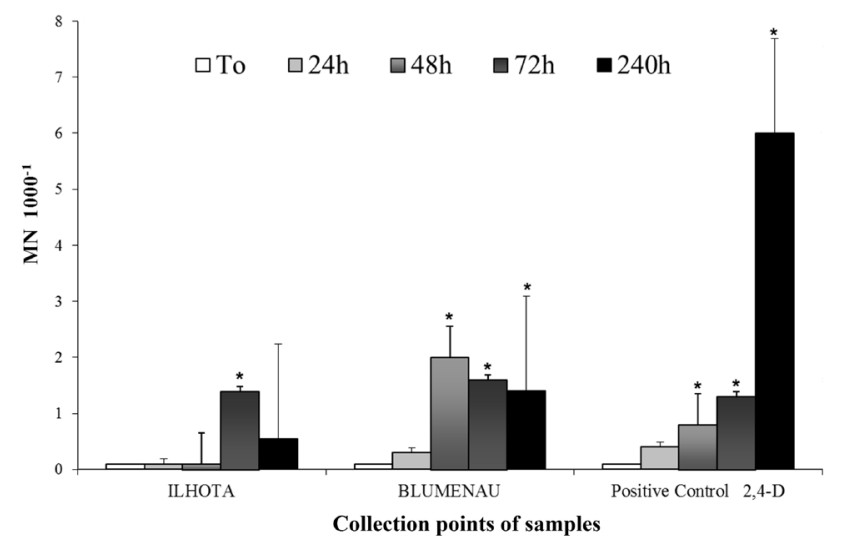

Figure 2. Mean number of micronuclei (MN $1000^{-1}$ erythrocytes) after exposure to water samples from Itajaí-Açú River in Ilhota and Blumenau cities. The bars represent the SE values. Positive control as 2,4-D (75 ppm). $* \mathrm{p}<0.05$ indicates difference from the $\mathrm{T}_{0}$ using the Mann Whitney $-U$ test.

Grisolia \& Cordeiro (2000) utilized different substances known to be mutagenic (e.g. cyclophosphamide, mitomycin C) and compared the effects over three species, Oreochromis niloticus; Cyprinus carpio and Tilapia rendalli, the last one showed to be more sensitive when compared to the others using the MNT. Porto et al. (2005) utilizing MNT to evaluate the genotoxic effect of mercury pollution over Amazonian fish species concluded that MNT in fish erythrocytes may be useful for indicating genotoxity of mercury in Amazon Rivers.

In the MNT, the results for Ilhota showed lower rates of genotoxic effects in tilapia erythrocytes, than was found for Blumenau, having significant effects only at $72 \mathrm{~h}$ of exposure, despite being a downstream sample site from Blumenau city which is a large city. In the Blumenau, the results showed high-rates of genotoxic effects since $48 \mathrm{~h}$ of exposure up to the last time analyzed $240 \mathrm{~h}$ (10 days). This can be attributed to the large population of the Blumenau city, the activity of several industries, and therefore to its considerable proportion of contaminants discharged on the river (Resgalla-Jr et al., 2008). The results suggest that this pollution load may be diluted along the way down, since it receives the input of several minor water streams, or it may be that much of the genotoxicants sediment at the river bed, so that when the waters reach Ilhota they are already alleviated from much of the genotoxicants input of Blumenau. Work of White \& Rasmussen (1998), suggest that household organic waste and a small amount of industrial waste are those most responsible for genotoxic effects in aquatic systems and associated biota.

\section{Alkaline comet assay}

The comet assay has been demonstrated to be a powerful tool for measuring the relationship between DNA damage and the exposure of aquatic organisms to genotoxic pollutants on environmental (Andrade et al., 2004b). This study provides data which will be useful for future work involving the biomonitoring of regions of the Itajaí-Açú River what it is important because the assessment of genotoxic effects is crucial to any comprehensive study of contaminants in aquatic environments. According to data in this study and the criteria established by Hartmann et al. (2004), the DNA is sensitive to pollutant exposure and effects (DNA breakage) serve as an early warning parameter. According by Lemos et al. (2005) to preserving the organism and ecosystem, the comet assay is a non-invasive and non-destructive methodology.

Figure 3 shows the mean of the sum of the ranks for the comet analysis. An increase in damaged nucleoids with increasing exposition time can be seen for both sampling points, revealing a time-dependent relationship between exposure and damage level in fish erythrocytes.

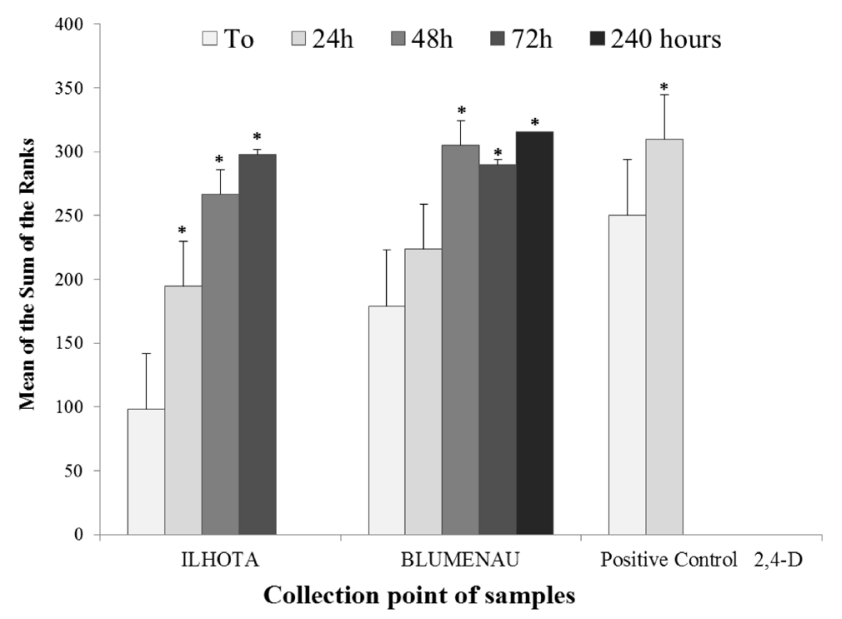

Figure 3. Mean sum of the ranks on different exposure times to water samples from Itajaí-Açú River in Ilhota and Blumenau cities. The bars represent the SE values. Positive control as 2,4-D (75 ppm). *p $<0.05$ indicates difference from the $\mathrm{T}_{0}$ using the Mann Whitney $-U$ test.

Genotoxic effects were observed by comet assay on erythrocytes of fishes exposed to the waters of the Itajaí-Açú River in both sample sites (Ilhota and Blumenau). The level of damage found in both sample sites for higher exposure times is similar to the effects observed in the positive control group, where the samples showed a significant amount of damage. In the case of Ilhota, there was a significant increase in the mean of the sum of the ranks $(\mathrm{p}<0.05)$ already for $24 \mathrm{~h}$ of exposure. The effects were also time-dependent, since the values increased steadily with time up to $72 \mathrm{hs}$. In sample point of Blumenau, the comet assay showed no significant difference between $\mathrm{T}_{0}$ and $24 \mathrm{~h}$ of exposure, however for the remaining times the damage showed a gradual increase from 48, 72 until $240 \mathrm{~h}$ (10 days) (Fig. 3). It was also noticed that there was an increase in the number of cells in the higher damage classes, when the exposure time increases (data not shown). On the other hand, the number of cells in the class I of damage was not showed to increase, suggesting a reduction of viable cells during exposure time. Bücker et al. (2006) in a study to evaluate the genotoxic action of benzene $(50 \mathrm{ppm})$ in different specimens of electric fish (Eingenmannia virescens) also using MNT and Comet assay found similar results to those reported here.

It was unexpected the high level of DNA damage exhibited by the negative control of the herbicide 2,4-D exposure in the 
comet assay. The most probable explanation for this are space and competition stress, since in this case 12 individuals were maintained in buckets of 30 liters of capacity, whereas for the river water testing 10 fish were exposed in 500 liter tanks filled with 200 liters of water. This points to unexpected effects of fish density and swimming space in generating an increase in DNA damage, possibly related to oxidative stress, which need further studies, but does not affect the results obtained for the river waters in the present work, since each experiment (actually each fish) has its own negative control.

The comet assay revealed significant DNA damage of the river water of both sites since the first analysis time up. When we compare the results between MNT and the comet assay for both sample sites it can be observed that for Ilhota only at the $72 \mathrm{~h}$ exposure time significant $\mathrm{MN}$ effects are present, whereas for Blumenau the MNT detected mutagenic effects already from $48 \mathrm{~h}$ up, what may be explained by the higher load of pollutants in this sample site. These results corroborate the sensitivity and speed of the comet assay in readily detecting DNA damaging agents in comparison to the MNT, because it does not depend on cell division. On the other hand, the MNT reveals that part of this DNA damage cannot be repaired, actually leading to irreversible mutations - highlighting the usefulness of utilizing both tests in combination.

The species $O$. niloticus demonstrated to be a sensitive organism to pollution and showed a pattern of DNA damage for environmental testing, thereby proving to be an adequate bioindicator of genotoxicity of river waters. A more realistic assessment could be provided by the analysis of native freeswimming fish caught from the polluted environment, and the comparison with fish of the same species caught from a reference area (Grisolia et al., 2009), which involves a more complicated setting. However, this study suggests that a monitoring program for the waters of this river using the exposure of the organisms in situ and continuously over time would be important. In conclusion, both techniques MNT and comet assay were effective and complementary to detect the presence of genotoxic effects in the tilapia erythrocytes, indicating that this fish can be used as a relevant parameter for biomonitoring the genotoxicity of aquatic environments.

\section{ACKNOWLEDGMENTS}

The authors wish to thank the CASAN (Companhia Catarinense de Águas e Saneamento) for providing field facilities. Dra. Angelica Francesca Maris (Universidade do Oeste de Santa Catarina - UNOESC) provided much valuable input in the final stages of the manuscript. This research was supported by Fundação de Apoio à Pesquisa Científica e Tecnológica do Estado de Santa Catarina - FAPESC and by the Universidade do Vale do Itajaí - UNIVALI.

\section{REFERENCES}

AL-SABTI, K., \& METCALFE, C. D., 1995, Fish micronuclei for assessing genotoxicity in water. Mutat. Res., 343: 121-135.

ANDRADE, V. M., SILVA, J., SILVA, F. R., HEUSER, V. D.,
DIAS, J. F., YONEAMA, M. L. \& FREITAS, T. R. O., 2004a, Fish as bioindicators to assess the effects of pollution in two southern brazilian rivers using the comet assay and micronucleus test. Environ. Mol. Mutag., 44: 459-468. doi: 10.1002/em.20070

ANDRADE, V. M., FREITAS, T. R. O. \& SILVA, J., 2004b, Comet assay using mullet (Mugil sp.) and sea catfish (Netuma sp.) erythrocytes for the detection of genotoxic pollutants in aquatic environment. Mutat. Res., 560: 57-67. doi: 10.1016/j. mrgentox.2004.02.006

ATEEQ, B., FARAH, M. A., ALI, M. N. \& AHMAD, W., 2002, Induction of micronuclei and erythrocyte alterations in the catfish Clarias batrachus by 2,4-dichlorophenoxyacetic acid and butachlor. Mutat. Res., 518: 135-144. doi: 10.1016/S13835718(02)00075-X

BARNHOORN, I. E. J. \& VAN VUREN, J. H. J., 2004, The use of different enzymes in feral freshwater fish as a tool for the assessment of water pollution in South Africa. Ecotoxicol. Environ. Saf., 59: 180-185. doi: 10.1016/j.ecoenv.2003.09.004

BELPAEME, M., COOREMAN, K. \& KIRSCH-VOLDERS, M., 1998, Development and validation of the in vivo alkaline comet assay for detecting genomic damage in marine flatfish. Mutat. Res., 415: 167-184.

BUSCHINI, A., MARTINO, A., GUSTAVINO, B., MONFRINOTTI, M., POLI, P., ROSSI, C., SANTORO, M., DORR AJM \& RIZZONI, M., 2004, Comet assay and micronucleus test in circulating erythrocytes of Cyprinus carpio specimens exposed in situ to lake waters treated with disinfectants for potabilization. Mutat. Res., 557: 119-129. doi: 10.1016/j. mrgentox.2003.10.008

BÜCKER, A., CARVALHO, W. \& ALVES-GOMES, J.A., 2006, Avaliação da mutagênese e genotoxicidade em Eigenmannia virescens (Teleostei: Gymnotiformes) expostos ao benzeno. Acta Amaz., 36(3): 357-364. doi: 10.1590/S004459672006000300011

BÜCKER, A., CARVAlHO, M. S. CONCEIÇÃO, M. B. \& ALVES-GOMES, J. A., 2012, Micronucleus test and comet assay in erythrocytes of the Amazonian electric fish Apteronotus bonapartii exposed to benzene. J. Braz. Soc. Ecotoxicol., 7(1): 65-73. doi: 10.5132/jbse.2012.01.010

CARVALHO, M. S., BÜCKER, A. \& ALVES-GOMES, J. A., 2006, Avaliação da genotoxicidade por frequência de micronúcleos e outras anomalias em eritrócitos de Apteronotus bonapartii (Teleostei: Gymnotiformes) expostos ao benzeno (25 ppm). In: $9^{\circ}$ ECOTOX - Encontro Brasileiro de Ecotoxicologia. São Pedro, São Paulo.

CHRISTOFOLETTI, C. A., DAVID, J. A. O. \& FONTANETTI, C. S., 2009, Application of the comet assay in erythrocytes of Oreochromis niloticus (Pisces): A methodological comparison. Genet. Mol. Biol., 32: 155-158. doi: 10.1590/S141547572009005000020

ClAXTON, L. D., HOUK, V. S. \& HUGHES, T. J., 1998, Genotoxicity of industrial wastes and effluents. Mutat. Res., 410: 237-243.

FAO (Food and Agriculture Organization), 1998, Aquaculture production statistics 1987-1996 - FAO Fisheries Circular 815, Revision 10, 197 pp.

FRENZILLI, G., NIGRO, M. \& LYONS, B. P., 2009, The Comet assay for the evaluation of genotoxic impact in aquatic environments. Mutat. Res., 681: 80-92. doi: 10.1016/j.mrrev.2008.03.001

GRISOLIA, C. K. \& CORDEIRO, C. M. T., 2000, Variability in micronucleus induction with different mutagens applied to several species of fish. Genet. Mol. Biol., 23: 235-239. doi: 10.1590/S1415-47572000000100041

GRISOLIA, C. K., RIVERO, C. L. G., STARLING, F. L. R. M., 
SILVA, I. C. R., BARBOSA, A. C. \& DOREA, J. G., 2009, Profile of micronucleus frequencies and DNA damage in different species of fish in a eutrophic trocial lake. Genet. Mol. Biol., 32(1): 138-143. doi: 10.1590/S1415-47572009005000009

HARTMANN, A., SCHUMACHER, M., PLAPPERT-HELBERG, U., LOWE, P., SUTER, W. \& MUELLER, L., 2004, Use of the alkaline in vivo comet assay for mechanistic genotoxicity investigations. Mutagenesis, 19: 51-59. doi: 10.1093/mutage/ geg038

JHA, A. N., 2004, Genotoxicological studies in aquatic organisms: an overview. Mutat. Res., 552: 1-17. doi: 10.1016/j. mrfmmm.2004.06.034

LEMOS, N. G., DIAS, A. L., SILVA-SOUZA, A. T . \& MANTOVANI, M. S., 2005, Evaluation of environmental waters using the comet assay in Tilapia rendalli. Environ. Toxicol. Pharmacol., 19: 197201. doi: 10.1016/j.etap.2004.03.011

MAFFEI, F., CARBONE, F., CANTELLI-FORTI, G., BUSCHINI, A., POLI, P., ROSSI, C., MARABINI, L., RADICE, S., CHIESARA, E. \& HRELIA, P., 2009, Drinking water quality: An in vitro approach for the assessment of cytotoxic and genotoxic load in water sampled along distribution system. Environ. Int., 35: 1053-1061. doi: 10.1016/j.envint.2009.05.007

MASUTTI, M. B., ESPÍNDOLA, E. L. G., NOGUEIRA, A. M. \& SIMÕES, F. C. F., 2006, Sensibilidade a Cobre e Cromo por Oreochromis niloticus e Pistia stratiotes. J. Braz. Soc. Ecotoxicol., 1(1): 37-42. doi: 10.5132/jbse.2006.01.008

MORON, S. E., POLEZ, V. L. P., ARTONI, R. F., RIBAS, J. L. C. \& TAKAHASHI, H. K., 2006, Estudo de Alterações na Concentração dos Íons Plasmáticos e da Indução de Micronúcleos em Piaractus mesopotamicus Exposto ao Herbicida Atrazina. J. Braz. Soc. Ecotoxicol., 1(1): 27-30. doi: 10.5132/jbse.2006.01.006

PEREIRA-FILHO, J., SPILLERE, L. C. \& SCHETTINI, C. A. F., 2003, Dinâmica de nutrientes na região portuária do estuário do rio Itajaí-açu, SC. Rev. Atlântica 25(1): 11-20.
PORTO, J. I. R., ARAÚJO, C. S. O. \& FELDBERG, E., 2005, Mutagenic effects of mercury pollution as revealed by micronucleus test on three Amazonian fish species. Environ. Res., 97: 287-292. doi: 10.1016/j.envres.2004.04.006

RESGALlA JR., C., SOUZA, V. G. C., RÖRIG, L. R. \& SCHETTINI, C. A. F., 2008, Spatial and temporal variation of the zooplankton community in the area of influence of the ItajaíAçú river, SC (Brazil). Braz. J. Oceanogr., 56(3): 211-224. doi: 10.1590/S1679-87592008000300006

RUSSO, C., ROCCO, L., MORESCALCHI, M. A. \& STINGO, V., 2004, Assessment of environmental stress by the micronucleus test and the comet assay on the genome of teleost populations from two natural environments. Ecotoxicol. Environ. Saf., 57: 168-174. doi: 10.1016/S0147-6513(03)00027-7

SANTOS, N. E. S., 1996, Utilização da análise de "filière" com a variável ambiental "efluentes líquidos e estações de tratamento" no estudo de comportamento das indústrias têxteis do vale do Itajai - SC. Tese de Doutorado, Universidade do Vale do Itajaí, Santa Catarina.

SCHMIDT, W., 1975, The micronucleus test. Mutat. Res. 31: 9-15.

SILVA, J., FREITAS, T. R. O., MARINHO, J. R., SPEIT, G. \& ERDTMANN, B., 2000, An alkaline single-cell gel electrophoresis (comet) assay for environmental biomonitoring with native rodents. Genet. Mol. Biol., 23: 241-245. doi: 10.1590/ S1415-47572000000100042

SINGH, N. P., McCOY, M.T., TICE, R. R. \& SCHNEIDER, E. L., 1988, A simple technique for quantitation of low levels of DNA damage in individual cells. Exp. Cell Res. 175: 184-191.

TICE, R. R., AGURELL, E., ANDERSON, D., BURLINSON, B., HARTMANN, A., KOBAYASHI, H., MIYAMAE, Y., ROJAS, E., RYU, J-C. \& SASAKI, Y. F., 2000, Single cell gel/comet assay: guidelines for in vitro and in vivo genetic toxicology testing. Environ. Mol. Mutagen. 35: 206-221.

WHITE, P. A. \& RASMUSSEN, J. B., 1998, The genotoxic hazards of domestic wastes in surface waters. Mutat. Res. 410: 223-236. 